\title{
Potentialities of Renewable Energy in Victoria, Australia
}

\author{
Vinayagam Arangarajan, Aman Moung Than Oo, G M Shafiullah and Alex Stojcevski \\ Faculty of Science, Engineering and Built Environment, Deakin University, Melbourne 3125, Australia
}

Received: January 15, 2014 / Accepted: February 14, 2014 / Published: June 30, 2014.

\begin{abstract}
In utility power system, electricity demand is being covered largely by fossil fueled power generation, which contributes high level of GHG (greenhouse gas) emission and causes global warming worldwide. In order to reduce GHG emission level, most of the countries in the world targeting towards green energy that is power generation from RE (renewable energy) sources. In this paper, it is considered to study prospects of RE sources in particular, solar and wind in Victoria State which are abundant as compared to other sources of renewable. The wind and solar energy feasibility study and sensitivity analysis has been done for Victoria with the aid of HOMER (hybrid optimization model of electric renewable) simulation software. From the study, it has clearly evicted that wind energy combinational HPS (hybrid power system) has more contribution, and high potential than solar PV (photovoltaic) systems for a particular location. This study also investigates the influences of energy storage in the proposed HPS.
\end{abstract}

Key words: Renewable energy, hybrid power system, economic analysis, environmental analysis.

\section{Introduction}

Electricity demand is being covered largely by fossil fueled power generation that contributing significant amount of GHG (greenhouse gas) emission to atmosphere. GHG emission participates as root cause for global warming which make changes in global climate conditions; rise in earth surface temperatures which are accompanied by increase in droughts, rise in sea level, retreat of glaciers, greater wild fire, and more severe storms.

As per commitment under KYOTO protocol [1], the Australian government has targeted $20 \%$ of electricity generation from RE (renewable energy) in 2020 [2, 3]. In Australia, the RET (renewable energy target) has categorized into two schemes; namely LRET (large scale renewable energy target) and SRES (small scale renewable energy scheme). LRET supports large scale RE projects, like solar farm, wind farm, bio energy, and hydro power projects, whereas SRES supports solar PV (photovoltaic), solar heaters in households and small

Corresponding author: Vinayagam Arangarajan, Ph.D. student, research field: microgrid power system with renewable energy sources. E-mail: avinayag@deakin.edu.au. business [3].With the introduction of the national RET, all individual RET set at the State level including that the targets for the State of Victoria were rolled into the national target. The State of Victoria needs to make a significant contribution to help achieve the targeted $20 \%$ generation from RE (renewable energy) sources. RE installed capacity for Victoria State in year 2012 $(1,869 \mathrm{MW})$ was around $30.79 \%$ higher as compared to installed capacity in $2010(1,429 \mathrm{MW})$, whereas actual RE generation $(3,825 \mathrm{GWH})$ in year 2012 was around $45.32 \%$ higher as compared to $2010 \mathrm{RE}$ generation (3,825 GWH) [4].

Therefore, in line with the Victorian Government initiatives this study aiming to explore the prospects of RE in the Victoria. This study has been developed a HPS (hybrid power system) to investigate the economic and environmental benefits of RE systems for different locations of Victoria. As solar and wind resources are abundant [5] as compared to other renewables in the Victoria State, this study concentrated on only solar and wind energy generation. Initially, the most high potential locations for solar and wind energy generation has been identified based on the available data at Bureau of meteorological [5]. 
Later, the optimization and feasibility analysis of RE sources like solar and wind for Victoria State has been carried out to identify prospects of wind and solar energy sources on the basis of the following performance metrics: NPC (net present cost), COE (cost of energy), RF (renewable fraction), and GHG emission factors. Finally, this study explores four studied systems: wind/PV/grid-connected, wind/grid-connected, $\mathrm{PV} /$ grid-connected and only gird-connected system through sensitivity analysis and investigate the suitable conditions for a specific meteorological conditions. This study will be benefited for the utilities to facilitated large-scale RE integration in the Victoria State.

This paper is organized as follows: Section 2 discusses the availability of solar and wind in Victoria; Section 3 presents the details of HPS model; Section 4 describes HPS simulation and results analysis using HOMER (hybrid optimization model of electric renewable); Section 5 concludes the paper with future directions.

\section{Availability of Solar and Wind in Victoria}

This section presents the potential availability of solar and wind resource in Victoria State.

\subsection{Solar Energy}

Solar radiation from Sun can be used to produce solar energy, which is renewable one. Solar energy is clean, suitable for eco-friendly environment and it does not contribute any GHG emission in atmosphere. The total solar energy available from the Sun at the Earth's surface over a time is given in below Eq. (1) [6]:

$$
E=0.58 \cdot 3.6 \cdot 10^{-9} \cdot S_{n}
$$

where, $E$ is solar energy (EJ), $S$ is solar constant $\left(\mathrm{w} / \mathrm{m}^{2}\right)$, $n$ is number of hours, and $r$ is radius of earth in $\mathrm{km}$.

Solar energy is helpful to meet energy requirement of electrical and thermal loads with the help of energy conversion technologies; photovoltaic technology of solar cell, concentrated solar power technology, solar water heater. Solar power is greatly depends on the solar insolation. Solar insolation is the amount of solar radiation at given time. Photovoltaic solar cell can be used for solar power generation by means of converting solar radiation into electrical energy. The energy conversion efficiency of solar cell is the relationship between maximum power output of solar cell to the solar insolation at given area. Solar cell efficiency is measured at STC (standard test condition). STC specifies at temperature of around $25{ }^{\circ} \mathrm{C}$ with an irradiance of 1,000 watts $/ \mathrm{m}^{2}$ and $1.5 \mathrm{AM}$ (air mass) of solar spectrum. Eq. (2) shows the details of solar insolation and Eq. (3) shows the solar cell efficiency in relationship with maximum power and solar insolation [7]:

$$
\begin{gathered}
\text { Solar insolation }(I)=E / A / D\left(\mathrm{kwh} / \mathrm{m}^{2} / \text { day }\right) \\
\text { Solar cell efficiency }=P_{m p} / E \cdot A\left(\mathrm{~m}^{2}\right)
\end{gathered}
$$

where, $E$ is energy, $D$ is period (day), $P_{m p}$ is maximum power, and $A$ is area.

Fig. 1 shows the solar exposure level of various locations in the Victoria State. Victoria's average annual global solar exposure on a horizontal surface ranges between 12-20 Mega joules per square meter per day $\left(\mathrm{MJ} / \mathrm{m}^{2} /\right.$ day $)$ [8]. The site location Mildurain Mallee district of Victoria State has higher solar potential $[5,8]$.

\subsection{Wind Energy}

Wind energy is a clean, free and nonpolluting sources of energy which does not contribute any GHG

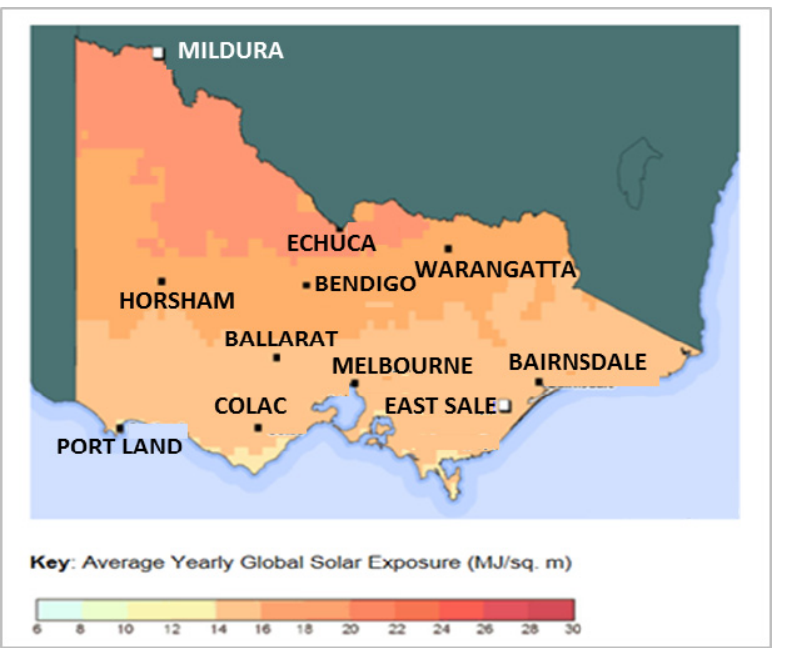

Fig. 1 Solar exposure level in Victoria [8]. 
emissions in the atmosphere. According to GWEC (Global Wind Energy Council), 12\% of global energy will be supplied by Wind power in 2020 [9]. At end of 2012, Global installed wind power production was around 282,430 MW [9]. Wind power is an intermittent and highly variable. Wind power generation is mainly depends on the wind speed. Eq. (4) shows the details of wind power in relationship with various factors [10-12]:

$$
\text { Wind power }\left(W_{p}\right)=C_{p} \cdot 1 / 2 \mathrm{p} a v^{3}
$$

where, $\mathrm{p}$ is air density $\left(1,225 \mathrm{~kg} / \mathrm{m}^{3}\right), v$ is the wind velocity in $(\mathrm{m} / \mathrm{sec}), a$ is rotor swept area in $\mathrm{m}^{2}$ and $C_{p}$ is the wind power co-efficient.

Fig. 2 shows the wind source availability in various locations of Victoria State. Best wind resources are available at southern and center coastal area and also in central district of Victoria State [13].

\subsection{Solar and Wind Potential in Victoria}

In order to identify solar and wind potential in Victoria State, solar exposure and wind speed data were collected from BOM (Bureau of Meteorology) of Australia [5]. There are 78 numbers of weather stations were considered from BOM. The locations orareas at which the solar exposure level, from $4.7 \mathrm{kWh} / \mathrm{m}^{2} /$ day to $5.2 \mathrm{kWh} / \mathrm{m}^{2} /$ day were considered as high solar potential areas, where as wind speed level from $5 \mathrm{~m} / \mathrm{sec}$ to $8.8 \mathrm{~m} / \mathrm{sec}$ were considered as high wind potential

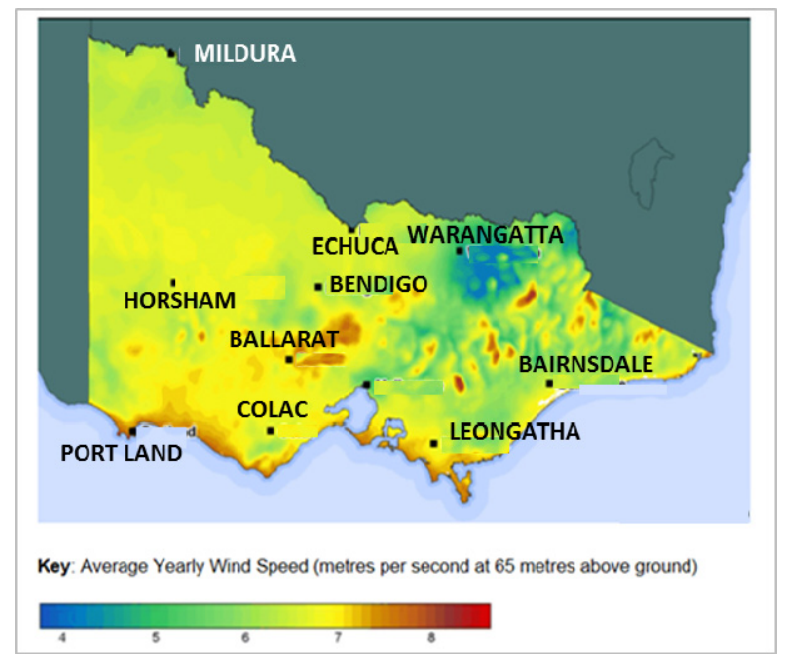

Fig. 2 Wind speed level in Victoria [13]. areas. Fig. 3 shows the details of wind and solar potential availability in various locations of Victoria State.

In considering potential of wind source, as Fig. 3 shows that annual monthly average wind speed level is very high in some locations of the following areas; South West district and its coastal area, central district and its coastal area, several locations of North East district, west and south Gippsland coastal area of Victoria State. The site locations; MountBuller, Falls creek and Mount Hotham in North East district, Point Wilson in Central, Cape Nelson and Cape Otway in coastal of South West district, Gabo island in East Gippsland district, Killmore gap in north central district, Wilsons Promontory in West-South Gippsland district are having high wind potential in the range of from $5.6 \mathrm{~m} / \mathrm{sec}$ to $8.8 \mathrm{~m} / \mathrm{sec}$ [5].

\section{Hybrid Power System Model}

The HPS model have been developed by using HOMER simulation software [14]. The HPS model has been configured with solar and wind power generation with grid connection facility. In this model, lead acid battery can be used as energy storage unit to support reliable integration of renewable power sources into the grid. In addition to this, the grid component can be considered as backup power source to fulfil energy requirement to the connected load in case of any shortage of power during deficit or absence of power output from solar and wind sources.

The HPS model helps to identify the cost and GHG emission factors of different combinational power systems in optimum level. Also enable to compares performances of different combinational hybrid power connected system based on performance metrics such as NPC, COE and RF. The areas with high potential of solar irradiation and wind speed were considered for this feasibility study. In this paper, optimization and sensitivity analysis of a HPS model has been performed with reference to the effects of variation in the wind speed and solar irradiation to get optimum level of 


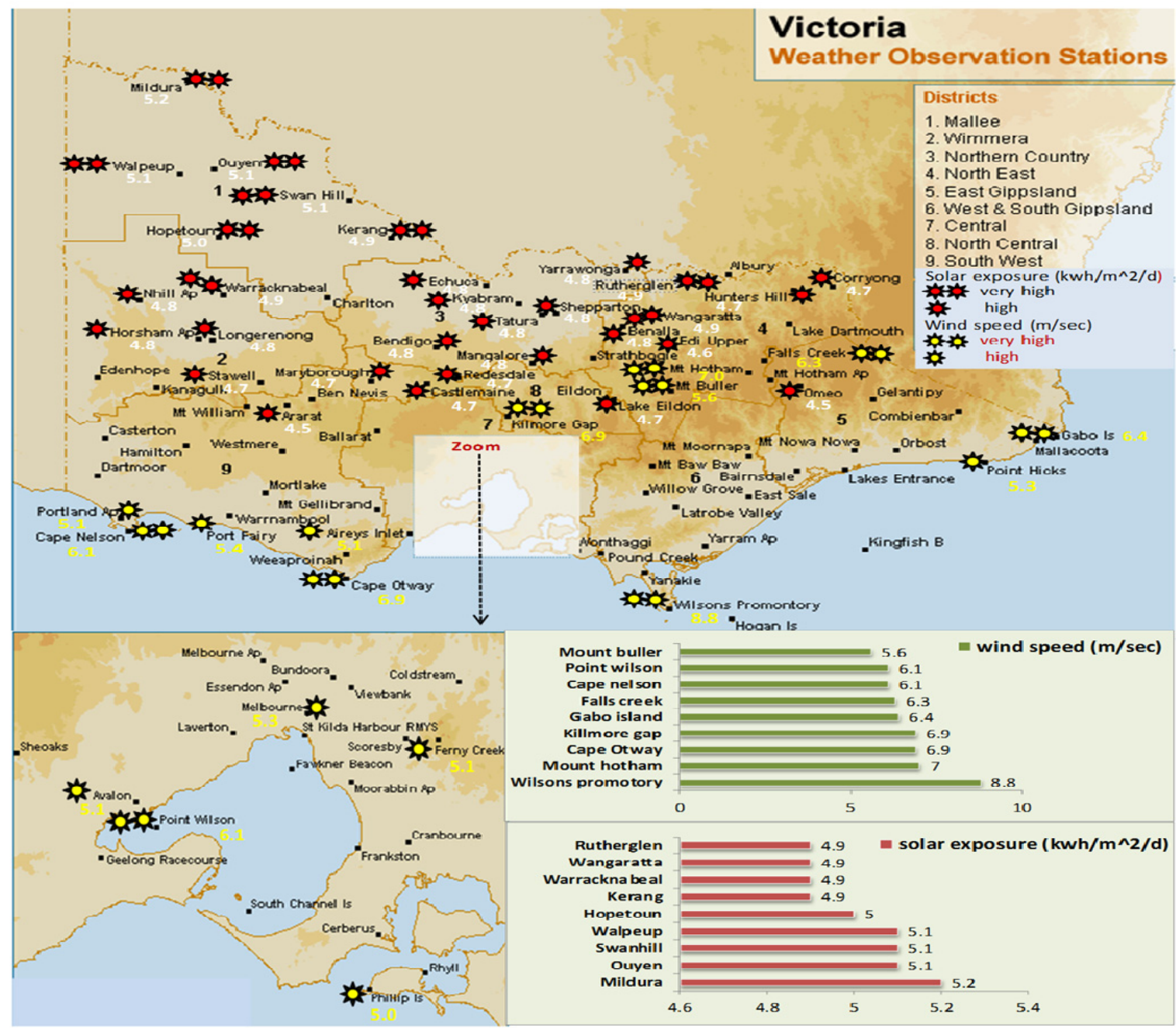

Fig. 3 Solar and wind resources potential in Victoria State.

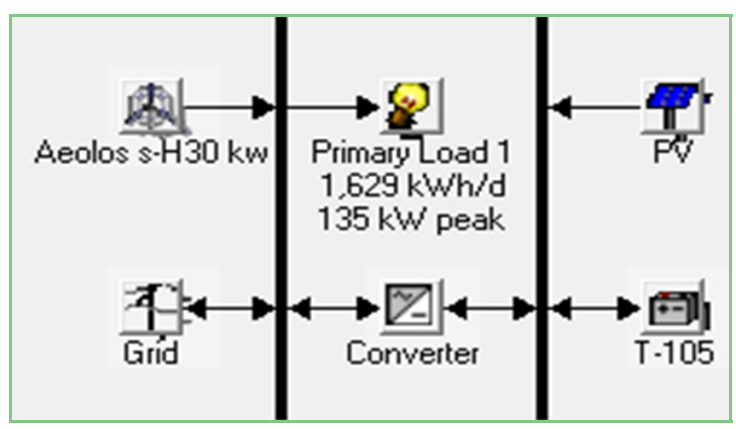

Fig. 4 HPS model [14].

NPC, COE, RF and GHG emission values as output results. Fig. 4 shows the configuration details of HOMER HPS model [14].

\subsection{Economic and Environment Factors}

The economic and environment indicators are considered to evaluate the sustainability of HPS model. NPC, COE, RF and environment related emission factors; $\mathrm{CO}_{2}$ (carbon dioxide), $\mathrm{SO}_{2}$ (sulphur dioxide), $\mathrm{NO}_{\mathrm{x}}$ (nitrous oxide) are considered as output results to develop efficient renewable power system [14]. For economic aspects, optimum level of NPC, COE are evaluated; whereas for environment aspects, reduction in GHG emission as well as RF values are identified.

\subsubsection{Economic Factors}

The NPC can be considered as a primary metric for cost evaluation of a power system and determines the life cycle cost of a power system. It is a present value of all costs that it incurs over a life time of a system, minus present value of all income over its life time. The NPC can be calculated as per the below Eq. (5) $[15,16]$ : 


$$
\begin{gathered}
\mathrm{NPC}(\$)=\mathrm{TAC} / \mathrm{CRF} \\
\mathrm{CRF}(\$)=i(1+i)^{N} /(1+i)^{N}-1
\end{gathered}
$$

where, $N$ is number of years, $i$ is annual real interest rate.

Total annual cost includes capital cost, replacement cost, operation and maintenance cost, fuel cost, emission penalties and purchasing cost of energy from grid.

COE is a levelized cost of energy as the average cost per KWh of useful electrical energy produced by the system. The total annual cost for producing electricity is divided by total useful electrical energy production. The Eq. (7) can be used to calculate COE:

$$
\operatorname{COE}(\$)=C_{\text {ann.Total }} / E
$$

where, $C_{\text {ann.Total }}$ is total annual cost, $E$ is electricity consumption in $\mathrm{KWh} /$ year.

\subsubsection{Environment Factors}

An emission factor is a representative value that relates the quantity of a pollutant which is released to the atmosphere with an associated activity. These factors are usually expressed as the weight of pollutant divided by duration of the activity emitting the pollutant. The HOMER simulation output results describe the total amount of each pollutant produced annually by a HPS model. As stated earlier, the gas emissions due to following gases; $\mathrm{CO}_{2}, \mathrm{SO}_{2}, \mathrm{NO}_{\mathrm{x}}$ are considered to evaluate as output emission level which are expressed in $\mathrm{Kg} / \mathrm{Y}$ ear. HOMER estimates emission level in negative value, in case of sell back low emission or emission free equivalent excess electricity to the grid $[14,17]$.

$\mathrm{RF}$ is the fraction of renewable energy contribution from RE power sources over annual total energy generation in hybrid power system.

$$
\begin{aligned}
f_{P V} & =E_{P V} / E_{\text {ann.Total }} \\
f_{W T} & =E_{W T} / E_{\text {ann. }} \text { Total }
\end{aligned}
$$

where, $E_{P V}$ is RE contribution of solar PV, $E_{P T}$ is RE contribution of wind power, $E_{\text {ann.Total }}$ is annual total energy generation.

Solar PV fraction $f_{P V}$ and wind power fraction $f_{W T}$ are represented as in above Eqs. (8) and (9) [18, 19].

\subsection{HPS Components}

The detailed specification of components that has been used in HPS model are summarised in this section as below.

\subsubsection{Solar PV (Photovoltaic)}

The capital cost for $1 \mathrm{~kW}$ Solar PV is assumed that around $\$ 2,100$ and cost for replacement is also considered as same price. The operation and maintenance cost are considered to be practically zero and the sizes of PV arrays are considered to vary from $50 \mathrm{~kW}$ to $200 \mathrm{~kW}$.

\subsubsection{Wind Turbine}

The Aeolos (s-H30) $30 \mathrm{~kW}$ wind turbine is considered for this HPS model study. The Aeolos wind turbine is manufactured by Aeolos wind energy limited, United Kingdom [20]. The capital cost for $30 \mathrm{~kW}$ wind turbine is considered around $\$ 66,080$ and replacement cost is assumed around $\$ 60,000$.

\subsubsection{AC/DC Converter}

In this model $\mathrm{AC} / \mathrm{DC}$, converter can be used as bidirectional converter, it can be used either as a rectifier or as an inverter. The capital cost for $1 \mathrm{~kW}$ converter is considered around $\$ 800$ and replacement cost is around $\$ 700$.

\subsubsection{Energy Storage: Battery}

In this model, T-105 Trojan deep cycle flooded lead acid battery is considered as energy storage device. The rated output voltage of each battery is around $6 \mathrm{~V}$ with ampere hour rating of around $225 \mathrm{Ah}$ [21]. In this HPS model, four batteries are considered in each string, total Watt hour capacity of each string is around $5.4 \mathrm{kWh}$. The SOC (state of charge) for battery storage is considered around $40 \%$. The capital cost is considered around \$210 and replacement cost is assumed around $\$ 210$ [21].

\subsubsection{Electrical Load}

Typical scaled annual monthly average load for Victoria State is considered for this HPS model study. The scaled annual average load is around 1,629 $\mathrm{kWh} /$ day. Fig. 5 shows the details of typical scaled annual electrical load profile with peak/average load of 


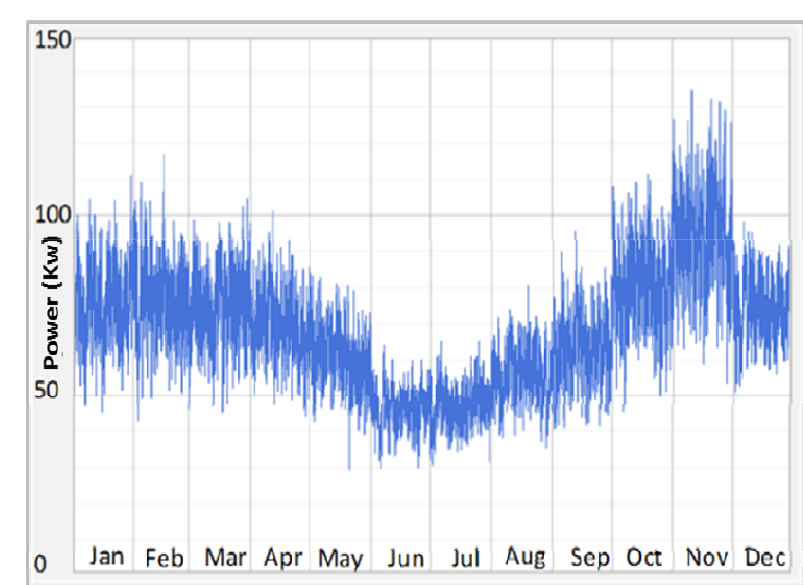

Fig. 5 Annual electrical load profile.

around $135 \mathrm{~kW} / 67.5 \mathrm{~kW}$.

\subsubsection{Grid System}

Grid system is considered as backup power source during peak demand time, in case of any output power shortage from solar and wind sources or insufficient energy reserve in connected storage system. In this HPS model study, the cost of energy which is purchased from grid is considered in two rates: 0.3 $\$ / \mathrm{kWh}$ (normal rate), $0.5 \$ / \mathrm{kWh}$ (peak rate); whereas sell back energy cost to grid is considered around 0.05 $\$ / \mathrm{kWh}$. The HOMER considers the GHG emission level equivalent to in terms of weight per unit of energy from power system $(\mathrm{g} / \mathrm{kWh})$, for $\mathrm{CO}_{2}$ which is around $632 \mathrm{~g} / \mathrm{kWh}$, for $\mathrm{SiO}_{2} 2.74 \mathrm{~g} / \mathrm{kWh}$, whereas for $\mathrm{No}_{\mathrm{x}}$ is around $1.34 \mathrm{~g} / \mathrm{kWh}$ [5].

\subsubsection{RE Sources}

For feasibility analysis, the solar radiation and wind speed data of Victoria State were collected from BOM, Australia. There are 78 numbers of weather stations in nine districts of Victoria State were considered for solar and wind generation. Out of 78 site locations, the locations with high potential availability of solar and wind resources were identified. From the data analysis, it has been clearly evident that a location with high solar potential having poor wind source and vice versa. This study selected one location from each district considering both solar and wind potential and hence nine locations have been selected from nine district in the Victoria State and developed HPS to investigate the prospects of RE in the Victoria. Out of nine locations, three locations were selected based on high solar potential irrespective of wind, whereas remaining six locations were selected based on high wind potential irrespective of solar. Table 1 shows the nine locations of average annual solar irradiation and wind speed data with corresponding latitude and longitude co-ordinates in which first three locations were selected based on high solar potential area and remaining six were selected based on high wind potential area.

Fig. 6 shows the graphical representation of typical annual solar irradiation of Mildura site at the Mallee district. The monthly annual average solar irradiation $\left(5.2 \mathrm{kWh} / \mathrm{m}^{2} / \mathrm{d}\right)$ is high in Mildura as compared to other locations in Mallee district [5]. Fig. 6 clearly shows that the solar exposure level is low from April to September, whereas rest of the months in year is higher [5].

Fig. 7 shows the graphical representation of typical annual wind speed pattern of Wilsons Promontory area, at West/South Gippsland district. The wind potential

Table 1 Solar irradiation and wind speed data [5].

\begin{tabular}{lllll}
\hline Site locations & $\begin{array}{l}\text { Latitude } \\
(\text { south) }\end{array}$ & $\begin{array}{l}\text { Longitude } \\
(\text { east })\end{array}$ & $\begin{array}{l}\text { Solar } \\
\left(\mathrm{kwh} / \mathrm{m}^{2} / \mathrm{d}\right)\end{array}$ & $\begin{array}{l}\text { Wind } \\
(\mathrm{m} / \mathrm{sec})\end{array}$ \\
\hline Mildura & $34.24^{\circ}$ & $142.09^{\circ}$ & 5.2 & 3.8 \\
Waraknabeal & $34.26^{\circ}$ & $142.41^{\circ}$ & 4.9 & 3.4 \\
Yarrawonga & $36.03^{\circ}$ & $146.03^{\circ}$ & 4.9 & 4.1 \\
Mt. Hotham & $36.98^{\circ}$ & $147.13^{\circ}$ & 4.3 & 7.0 \\
Gapo Island & $37.57^{\circ}$ & $149.92^{\circ}$ & 4.3 & 6.4 \\
W. Promontory & $39.13^{\circ}$ & $146.42^{\circ}$ & 4.2 & 8.8 \\
Point Wilson & $38.10^{\circ}$ & $144.54^{\circ}$ & 4.3 & 6.1 \\
Killmore Gap & $37.38^{\circ}$ & $144.97^{\circ}$ & 4.3 & 6.9 \\
Cape otway & $38.86^{\circ}$ & $143.51^{\circ}$ & 4.1 & 6.9 \\
\hline
\end{tabular}

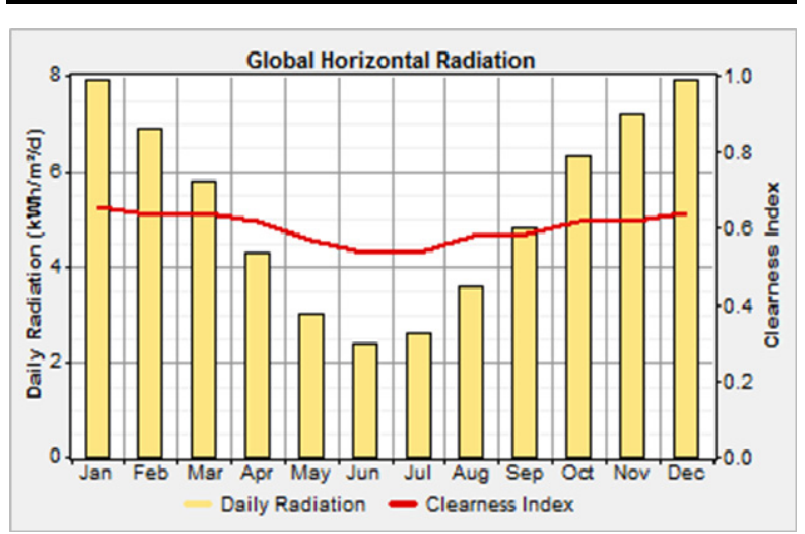

Fig. 6 Annual average solar exposure. 


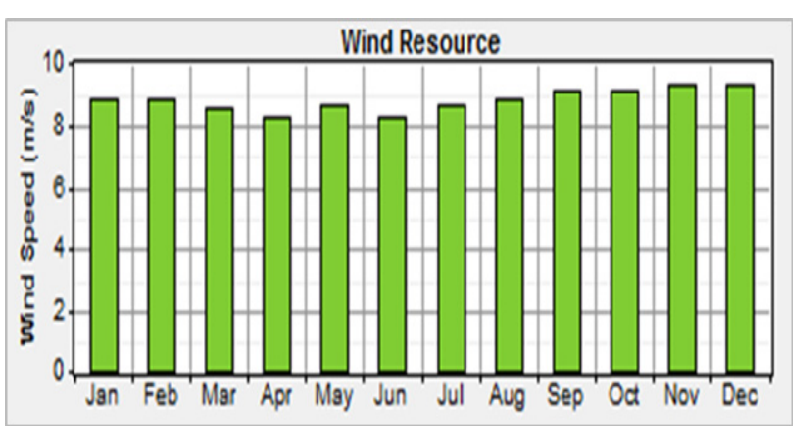

Fig. 7 Annual average wind resource.

is very high throughout the year in Wilsons Promontory as compared to other locations [5]. The monthly average wind speed is more than $9 \mathrm{~m} / \mathrm{sec}$ for the month of September to December, whereas more than $8.5 \mathrm{~m} / \mathrm{sec}$ in rest of the months [5].

\section{Results Analysis}

\subsection{Optimization Analysis}

In order to compare and identify the optimum level of economic and emission factors, this study considered

$\mathrm{PV} /$ grid-connected, $\mathrm{PV} /$ wind/grid-connected, wind/grid-connected and gird-only systems. Economic factors of the studied systems were measured by NPC and COE while emission factors of the systems were measured by RF and $\mathrm{CO}_{2}$ emissions. Table 2 depicts the optimization results of the four studied system for the selected nine locations.

From the above Table, it is clearly shows that the $\mathrm{PV} /$ grid power system is more feasible in economic and emission point of view as compared to wind/grid-connected and grid-only system in three locations: Mildura, Warracknabeal and Yarrawonga. Similarly, it has shown that the wind/grid and wind/PV/grid system are more feasible as compared to $\mathrm{PV} /$ grid and grid-only in economic and environment aspects for the remaining six locations. This is due to availability of higher wind potential than the solar in these locations. Finally, from the results of above nine locations, it can be evident that wind has more potentialities compare to solar energy as wind can generate energy throughout the day while solar can
Table 2 Optimization results of HPS model (nine site locations).

\begin{tabular}{|c|c|c|c|c|}
\hline Mildura & $\mathrm{PV} /$ grid & $\mathrm{PV} /$ wind/grid & Wind/grid & Grid-only \\
\hline NPC (\$) & $2,201,429$ & $2,427,965$ & $2,745,961$ & $2,817,551$ \\
\hline $\operatorname{COE}(\$ / \mathrm{kwh})$ & 0.29 & 0.319 & 0.361 & 0.371 \\
\hline $\mathrm{RF}(\%)$ & 47 & 65 & 30 & 0 \\
\hline $\mathrm{CO}_{2}(\mathrm{~kg} /$ year $)$ & 209,412 & 86195 & 252,560 & 375,777 \\
\hline Warracknabeal & $\mathrm{PV} /$ grid & PV/wind/grid & Wind/grid & Grid-only \\
\hline NPC (\$) & $2,259,747$ & $2,572,259$ & $2,907,279$ & $2,817,551$ \\
\hline $\operatorname{COE}(\$ / k w h)$ & 0.297 & 0.338 & 0.382 & 0.371 \\
\hline $\mathrm{RF}(\%)$ & 45 & 60 & 23 & 0 \\
\hline $\mathrm{CO}_{2}(\mathrm{~kg} /$ year $)$ & 219,302 & 127,360 & 283,834 & 375,777 \\
\hline Yarrawonga & $\mathrm{PV} /$ grid & $\mathrm{PV} /$ wind/grid & Wind/grid & I Grid-only \\
\hline NPC (\$) & $2,269,607$ & $2,371,487$ & $2,563,138$ & $2,817,551$ \\
\hline $\operatorname{COE}(\$ / k w h)$ & 0.299 & 0.312 & 0.337 & 0.371 \\
\hline $\mathrm{RF}(\%)$ & 45 & 68 & 39 & 0 \\
\hline $\mathrm{CO}_{2}(\mathrm{~kg} /$ year $)$ & 219,086 & 53,932 & 210,623 & 375,777 \\
\hline Mount hotham & $\mathrm{PV} /$ grid & PV/wind/grid & Wind/grid & 1 Grid-only \\
\hline NPC (\$) & $2,385,976$ & $1,465,295$ & $1,363,135$ & $2,817,551$ \\
\hline $\operatorname{COE}(\$ / \mathrm{kwh})$ & 0.314 & 0.193 & 0.179 & 0.371 \\
\hline $\mathrm{RF}(\%)$ & 40 & 90 & 87 & 0 \\
\hline $\mathrm{CO}_{2}(\mathrm{~kg} /$ year $)$ & 237,573 & $-487,801$ & $-410,534$ & 375,777 \\
\hline Gapo island & $\mathrm{PV} /$ grid & PV/wind/grid & Wind/grid & Grid-only \\
\hline NPC (\$) & $2,369,502$ & $1,627,679$ & $1,555,384$ & $2,817,551$ \\
\hline COE (\$/kwh) & 0.312 & 0.214 & 0.205 & 0.371 \\
\hline $\mathrm{RF}(\%)$ & 41 & 88 & 84 & 0 \\
\hline $\mathrm{CO}_{2}(\mathrm{~kg} /$ year $)$ & 231,729 & $-397,770$ & $-317,040$ & 375,777 \\
\hline W.Promontory & $\mathrm{PV} /$ grid & Wind/PV/grid & Wind/grid & Grid-only \\
\hline NPC (\$) & $2,407,541$ & $1,144,508$ & $1,013,055$ & $2,817,551$ \\
\hline COE (\$/kwh) & 0.317 & 0.151 & 0.133 & 0.371 \\
\hline RF (\%) & 39 & 94 & 92 & 0 \\
\hline $\mathrm{CO}_{2}(\mathrm{~kg} /$ year $)$ & 240,739 & $-686,000$ & $-610,479$ & 375,777 \\
\hline Point wilson & $\mathrm{PV} /$ grid & PV/wind/grid & Wind/grid & Grid-only \\
\hline NPC (\$) & $2,378,249$ & $1,750,988$ & $1,695,609$ & $2,817,551$ \\
\hline $\mathrm{COE}(\$ / \mathrm{kwh})$ & 0.313 & 0.23 & 0.223 & 0.371 \\
\hline RF (\%) & 40 & 86 & 81 & 0 \\
\hline $\mathrm{CO}_{2}(\mathrm{~kg} /$ year $)$ & 236,977 & $-335,821$ & $-258,080$ & 375,777 \\
\hline Kilmore gap & $\mathrm{PV} /$ grid & Wind/PV/grid & Wind/grid & 1 Grid-only \\
\hline NPC (\$) & $2,371,263$ & $1,471,066$ & $1,373,886$ & $2,817,551$ \\
\hline $\mathrm{COE}(\$ / \mathrm{kwh})$ & 0.312 & 0.194 & 0.181 & 0.371 \\
\hline $\mathrm{RF}(\%)$ & 41 & 90 & 87 & 0 \\
\hline $\mathrm{CO}_{2}(\mathrm{~kg} /$ year $)$ & 236,106 & $-488,907$ & $-410,602$ & 375,777 \\
\hline Cape otway & $\mathrm{PV} /$ grid & Wind/PV/grid & Wind/grid & Grid-only \\
\hline NPC (\$) & $2,412,209$ & $1,518,180$ & $1,422,599$ & $2,817,551$ \\
\hline $\mathrm{COE}(\$ / \mathrm{kwh})$ & 0.317 & 0.20 & 0.187 & 0.371 \\
\hline RF (\%) & 39 & 89 & 86 & 0 \\
\hline $\mathrm{CO}_{2}(\mathrm{~kg} /$ year $)$ & 242,824 & $-469,402$ & $-3,95,327$ & 375,777 \\
\hline
\end{tabular}

generate energy only for 7 hours to 8 hours a day.

Figs. 8 and 9 depict optimum results of $\mathrm{COE}$ and $\mathrm{CO}_{2}$ emission level respectively for high solar potential locations. From these figures, it is clearly evident that the Mildura is the best suitable location for solar energy generation both economically and environmentally. Figs. 10 and 11 depict optimum results of COE and 


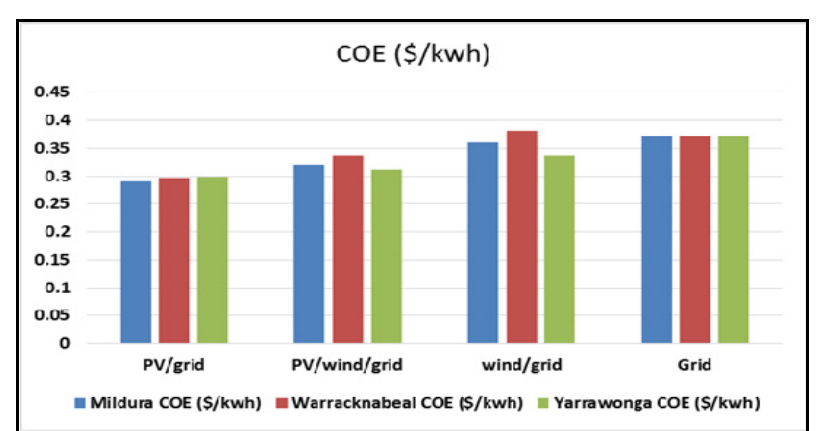

Fig. 8 COE results in high solar potential locations.

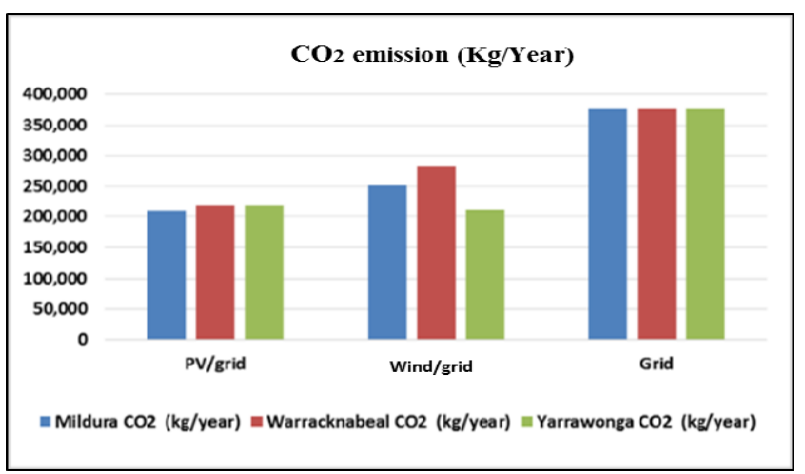

Fig. $9 \mathrm{CO}_{2}$ results in high solar potential locations.

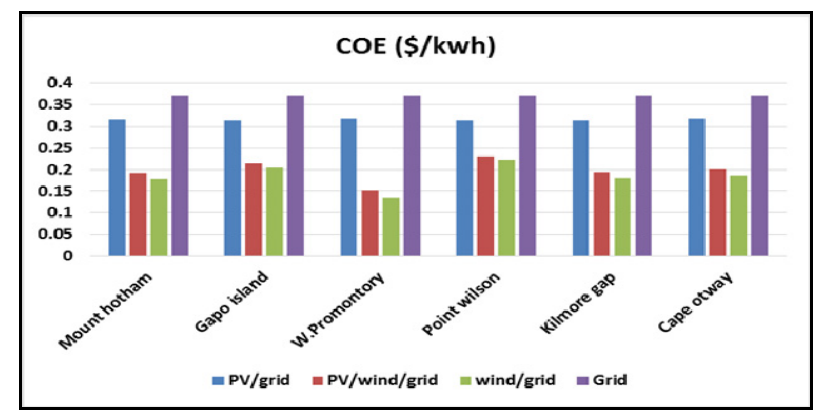

Fig. 10 COE results of high wind potential locations.

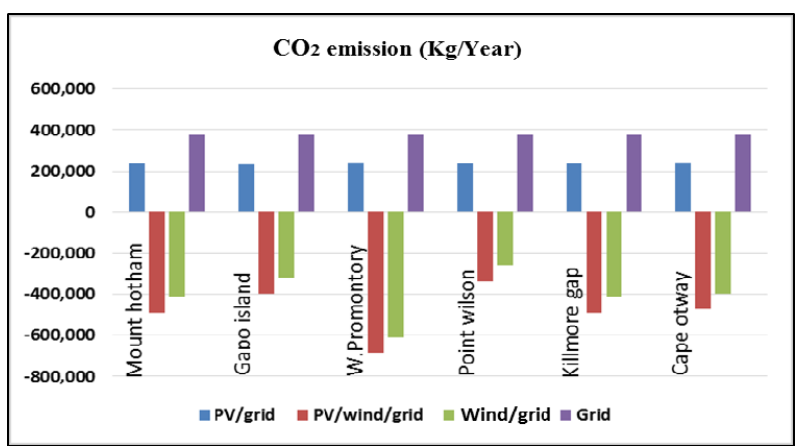

Fig. $11 \mathrm{CO}_{2}$ results of high wind potential locations.

$\mathrm{CO}_{2}$ emission level respectively for high wind potential locations. From Figs 10 and 11, it has seen that Wilson Promontory is the most preferred and Kilmore Gap is the second preferred while Point Wilson is the least preferred location for wind energy generation. Therefore, this study further explore the HPS model for Mildura, the most suitable location for solar energy generation and Wilson Promontory, the most suitable location for wind energy generation.

\subsection{Optimization Results for Mildura}

As stated earlier, the annual average solar potential is very high in Mildura site location as compared to other locations. In order to ensure further optimum level of economic and emission factors, Mildura has been considered for optimization and sensitivity analysis of HPS model. Fig. 12 shows the optimization results of HPS model with grid connected various combinational power systems. From Fig. 12, it has seen that $\mathrm{COE}$ and NPC in the PV/grid connected system is around $21.8 \%$ less than the standard grid system and $19.8 \%$ less than the wind/grid systems.

Among the studied systems, it can be stated that $\mathrm{COE}$ is the lowest for PV/grid connected system as shown in Fig. 13. On the other hand, from Fig. 14 it has seen that NPC is the lowest in the PV/grid connected system while the highest in the only-gird system.

From Table 3, it can be stated that the $\mathrm{CO}_{2}, \mathrm{SiO}_{2}$,

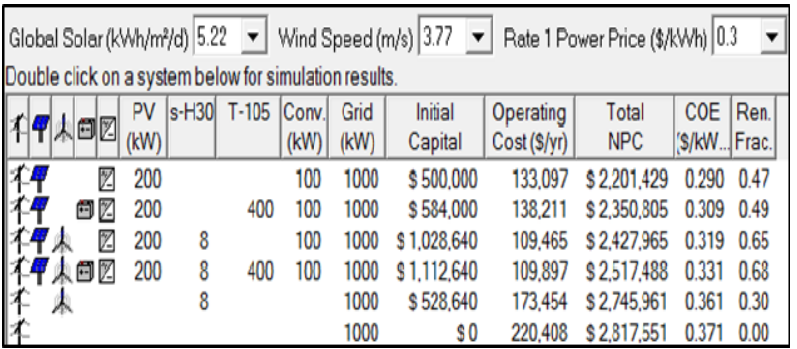

Fig. 12 HPS model feasibility analysis of Mildura.

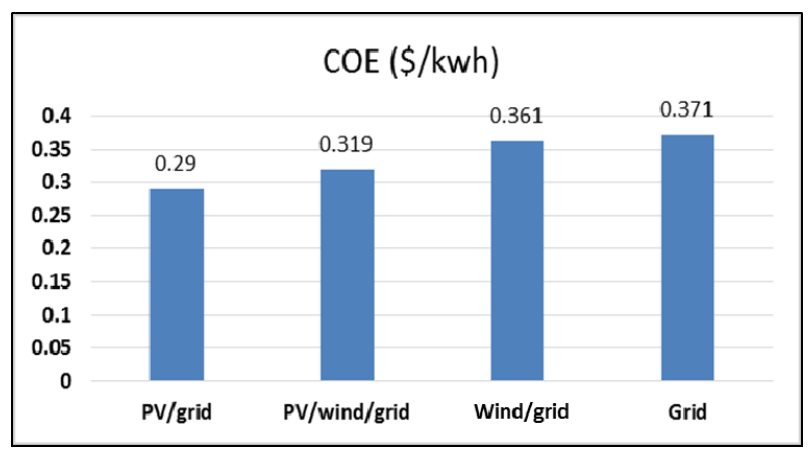

Fig. 13 Cost of energy $(\$ / k W h)$. 


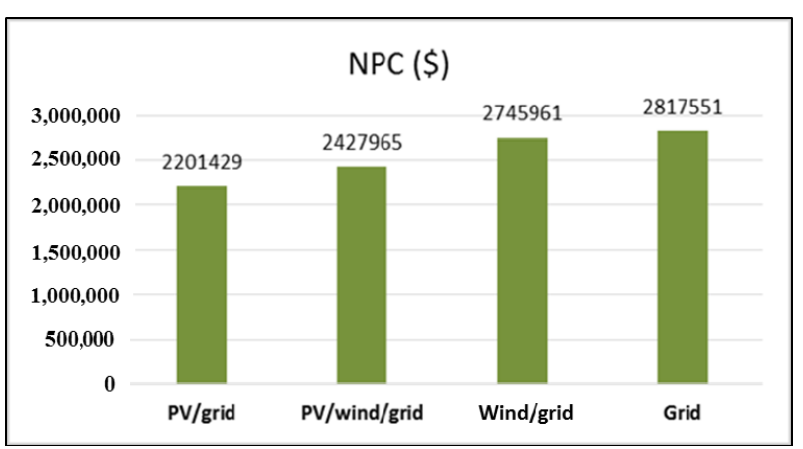

Fig. 14 Net present cost (\$).

Table 3 Emission factors (kg/year).

\begin{tabular}{llll}
\hline Power system & $\begin{array}{l}\mathrm{CO}_{2} \\
(\mathrm{~kg} / \text { year })\end{array}$ & $\begin{array}{l}\mathrm{SiO}_{2} \\
(\mathrm{~kg} / \text { year })\end{array}$ & $\begin{array}{l}\mathrm{NO}_{\mathrm{x}} \\
(\mathrm{kg} / \text { year })\end{array}$ \\
\hline $\mathrm{PV} /$ grid & 209,412 & 908 & 444 \\
Wind/grid & 252,560 & 1,095 & 535 \\
$\mathrm{PV} /$ wind/grid & 86,195 & 374 & 183 \\
Grid & 375,777 & 1629 & 797 \\
\hline
\end{tabular}

$\mathrm{NO}_{\mathrm{x}}$ emission level for $\mathrm{PV} /$ grid connected system is $44.3 \%$ less than standard grid system and $17.1 \%$ less than wind/grid connected system. These results clearly shows that $\mathrm{PV} /$ grid connected power system is more feasible than the wind/PV/grid, wind/grid and standard grid system in economic and environment point of view in Mildura.

\subsection{Optimization Results (Wilsons Promontory)}

The wind potential is very high in Wilsons Promontory as compared to other site locations in Victoria State. In order to ensure further optimum level of economic and emission factors, Wilsons Promontory has been considered for the optimization and sensitivity analysis of HPS model. Fig. 15 shows the feasibility analysis results of HPS model with grid connected various combinational power systems.

From the Table 4 results, it is observed that in the wind/grid connected system COE, NPC is around 64\% less than the grid-only and 58\% less than the PV/grid system. Figs. 16 and 17 show clearly that the $\mathrm{CO}_{2}, \mathrm{SiO}_{2}$ $\mathrm{NO}_{\mathrm{x}}$ emission level for wind/grid connected system is around $-610,479 \mathrm{~kg} /$ year, $-2,647 \mathrm{~kg} /$ year, and $-1,294$ $\mathrm{kg} /$ year equivalent to sellback of green energy around $965,947 \mathrm{kWh}$ to grid.

From these above results, it is clearly shows that the

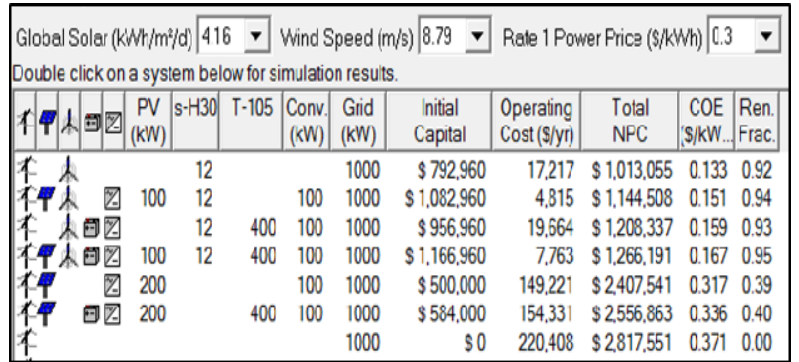

Fig. 15 HPS model feasibility analysis (Wilson Promontory).

Table 4 Economic factors $(\$)$.

\begin{tabular}{llll}
\hline Power system & NPC $(\$)$ & COE (\$/kwh) & RF (\%) \\
\hline Wind/grid & $1,013,055$ & 0.133 & 92 \\
Wind/PV/grid & $1,144,508$ & 0.151 & 94 \\
PV/grid & $2,407,541$ & 0.317 & 39 \\
Grid & $2,817,551$ & 0.371 & 0 \\
\hline \multicolumn{4}{c}{ CO2 emission(Kg/Year) } \\
\hline 600,000 & & & \\
400,000 & & & \\
200,000 & & & \\
0 & PV/wind/grid & wind/grid \\
$-200,000$ & & & \\
$-400,000$ & & & \\
$-600,000$ & & & \\
$-800,000$ & & & \\
\hline
\end{tabular}

Fig. $16 \mathrm{CO}_{2}$ emissions (kg/year).

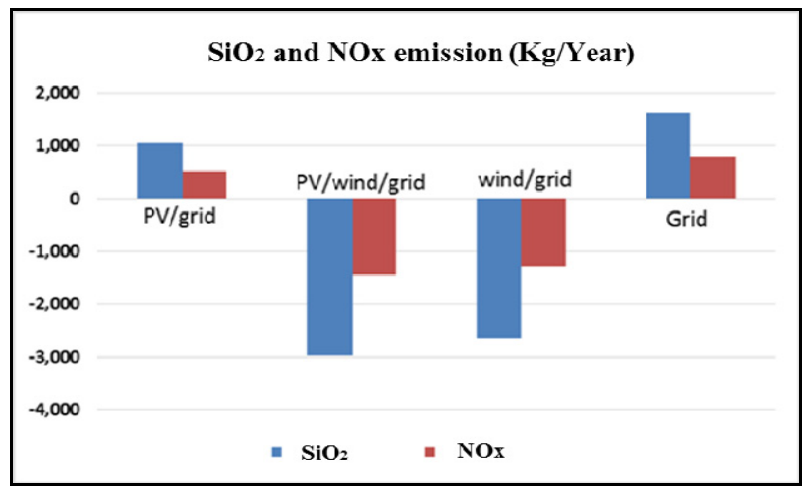

Fig. $17 \mathrm{SiO}_{2}$ and $\mathrm{NO}_{\mathrm{x}}$ emissions (kg/year).

Wind/grid and wind/PV/grid system provides significant reduction in GHG emission level as well as cost factors; NPC, COE as compared to standard grid and PV/grid system. This outcome also evident in the study by Shafiullah et al. [22] that the Wilsons Promontory site location was more feasible for wind power generation. 


\subsection{Sensitivity Analysis}

To identify the performance condition of a renewable power system, HOMER repeats its optimization analysis called sensitivity analysis for a given multiple values of any variable as input [14]. In this section, the sensitivity analysis has been carried out to study the performance of HPS by varying the solar irradiation and wind speed for different sites, such as Mildura and Wilsons Promontory.

The sensitivity analysis for Mildura has been carried out with six values of solar irradiation variables to estimate the performance of HPS model in COE and RF point of view. From Fig. 18, it can be shown that at $5.8 \mathrm{kWh} / \mathrm{m}^{2} / \mathrm{d}$ solar irradiation, the $\mathrm{COE}$ is around $0.266 \$ / \mathrm{kWh}$ and RF is $69 \%$. Similarly at $6.5 \mathrm{kwh} / \mathrm{m}^{2} / \mathrm{d}$, the COE is $0.262 \$ / \mathrm{kWh}$ and $\mathrm{RF}$ is $70 \%$. This indicates clearly that the higher solar irradiation contributes more fraction of renewable power with reduced cost of energy. In Mildura, during the months of January to March and October to December in a year, higher solar potential can get efficient renewable power generation with PV/grid power system.

Similarly, the sensitivity analysis for Wilsons Promontory has been carried out with six values of wind speed and solar irradiation to estimate the performance of HPS in $\mathrm{CO}_{2}$ emission point of view. In Fig. 19, for wind/grid system, the $\mathrm{CO}_{2}$ emission value is $-490,089 \mathrm{~kg} /$ year at wind speed of around $7.5 \mathrm{~m} / \mathrm{sec}$.
Similarly at wind speed $8.8 \mathrm{~m} / \mathrm{sec}$ that the $\mathrm{CO}_{2}$ emission value is further reduced to $-610,479 \mathrm{~kg} /$ year and at $9.3 \mathrm{~m} / \mathrm{sec} \mathrm{CO}_{2}$ emission is around $-637,121$ $\mathrm{kg} /$ year. These results clearly indicates that increasing in wind speed level contributes a significant reduction in $\mathrm{CO}_{2}$ emission. This analysis results shows that, higher wind potential benefits to get significant reduction in emission level.

\subsection{Beneficial Results of Energy Storage}

The lead acid battery is used as energy storage in HPS model simulation of Mildura site location. The battery can be used for RE time shift and smooth out power output variation of solar and wind generation. In this HPS model, Trojan T-105 deep cycle flooded lead acid battery with rated output voltage of $6 \mathrm{~V}, 220 \mathrm{Ah}$ capacity is considered as energy storage device. In each string, 4 numbers of batteries are considered with nominal capacity of $540 \mathrm{kWh}$. In consideration of $40 \%$ SOC, the usable capacity is around $378 \mathrm{kWh}$. Tables 5 and 6 show RF contribution and emission level output results of HPS model with and without storage conditions. With the integration of energy storage in the $\mathrm{PV} /$ grid system, RF has increased around $2 \%$ and purchase of grid power has reduced around $2 \%$. Therefore, it can be stated that increase of RF reflects to get the benefits of reduction in GHG emission level. Also, when compared with wind/PV/grid without

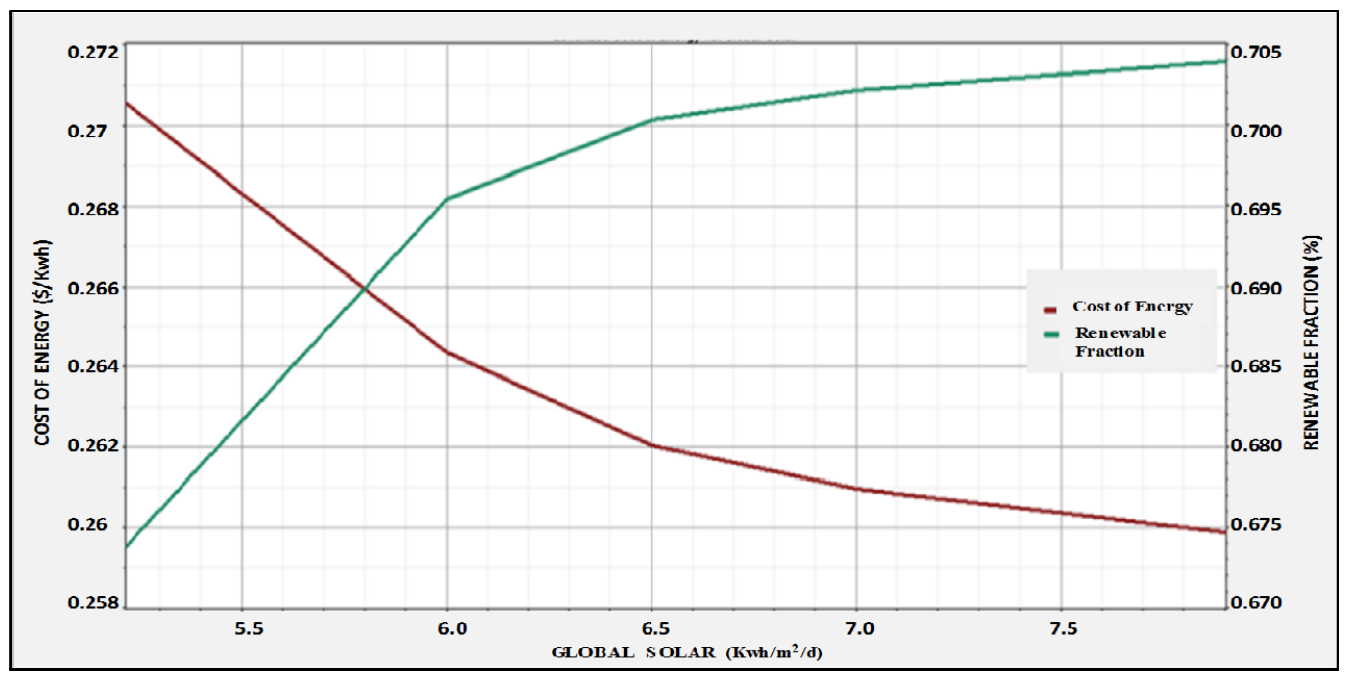

Fig. 18 Solar irradiation versus COE and RF (Mildura). 


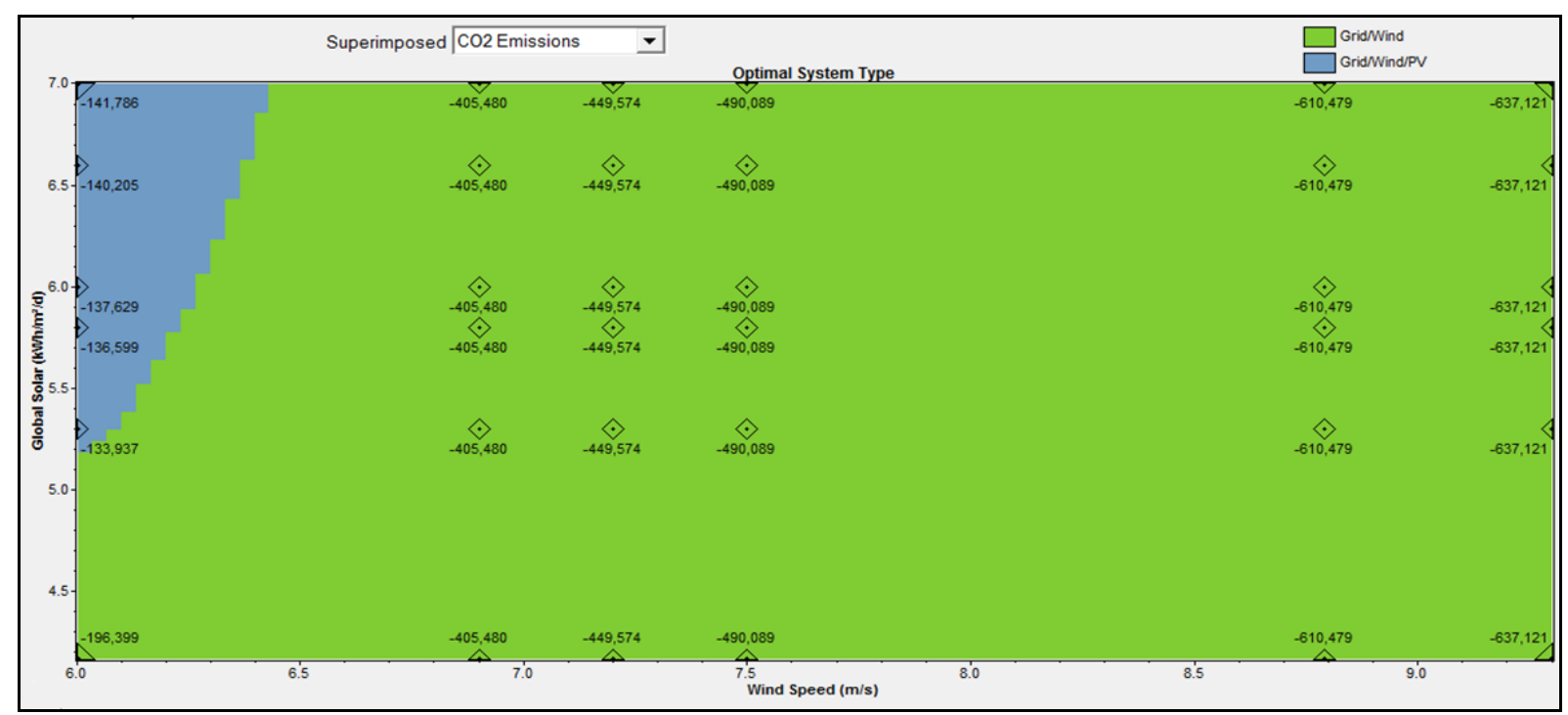

Fig. 19 Wind speed versus $\mathrm{CO}_{2}$ emissions (Wilsons Promontory).

Table 5 Output results (without storage).

\begin{tabular}{lll}
\hline Without storage & PV/grid & PV/wind/grid \\
\hline PV contribution & $47 \%$ & $41 \%$ \\
Wind contribution & ----- & $24 \%$ \\
Grid purchase & $53 \%$ & $35 \%$ \\
$\mathrm{CO}_{2}$ (kg/year) & 209,412 & 86,195 \\
$\mathrm{SiO}_{2}$ (kg/year) & 908 & 374 \\
$\mathrm{NOx}^{(\mathrm{kg} / \text { year) }}$ & 444 & 183 \\
\hline
\end{tabular}

Table 6 Output results (with storage).

\begin{tabular}{lll}
\hline With storage & PV/grid & PV/wind/grid \\
\hline PV contribution & $49 \%$ & $43 \%$ \\
Wind contribution & ----- & $25 \%$ \\
Grid purchase & $51 \%$ & $32 \%$ \\
$\mathrm{CO}_{2}$ (kg/year) & 204,147 & 81,148 \\
$\mathrm{SiO}_{2}$ (kg/year) & 885 & 352 \\
$\mathrm{NO}_{\mathrm{x}}$ (kg/year) & 433 & 172 \\
\hline
\end{tabular}

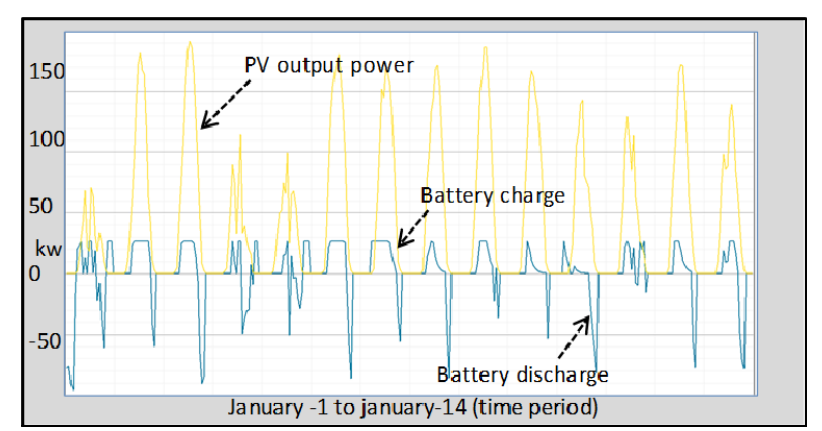

Fig. 20 Status of battery versus solar PV power.

storage system that the wind/PV/grid with storage system helps to get 3\% increase of overall RF (PV-2\% and wind- $1 \%$ ) and $3 \%$ reduction in purchasing of grid power. Similarly, 3\% incremental of RF reflects to get benefits of reduction in GHG emission level.
In Mildura, during the month of January, the average solar irradiation is around $7.9 \mathrm{kWh} / \mathrm{m}^{2} / \mathrm{d}$. Fig. 20 shows the first two week status of solar power output with battery usage condition. During this period, whenever the solar PV power output high, the battery gets charged while absence or deficit of solar power that the stored energy gets discharged to meet the load requirement. It has clearly shows that the battery storage increases the performances of HPS module, increases the energy generation and reduces the GHG emission.

\section{Conclusions and Future Directions}

This study developed a HPS to investigate the potentialities of RE in Victoria. Nine locations were considered one from each district of Victoria for optimization and feasibility analysis of renewable sources in particular, solar and wind resources to find out optimum level of economic and emission factors.

As per optimization and sensitivity analysis, it has evident that the Mildura is the most suitable location for solar energy generation and Wilsons Promontory is the most suitable location for wind energy generation. It has also seen that the use of energy storage in the HPS increases overall RF and reduces purchase of grid power. This overall increment of RF contribution causes in reduction of GHG emission level. This model 
of study also indicates that the wind combinational power systems: wind/grid, wind/PV/grid at high wind potential areas are more feasible than feasibility of $\mathrm{PV} /$ grid system in high solar potential areas.

This research study will be helpful to researchers and power utilities by further analysis of RE sources at high level to develop efficient renewable power generation in the Victoria State. This will helps to develop efficient renewable power generation in Victoria and support to achieve 20\% RET in 2020 for Australia.

Along with this basic study, further in depth investigations and research analysis are required in the following areas:

Investigate integration challenges of RE sources to modern power system;

Develop high level of efficient renewable power generation in Victoria State.

\section{References}

[1] Kyoto Protocol, UNFCCC (United Nations Framework Convention on Climate Change) 1997 [Online], http://unfccc.int/kyoto_protocol/items/2830.php (accessed Dec.12, 2013).

[2] Renewable energy target review, Australian Government Climate Change Authority 2012 [Online], http://climatechangeauthority.gov.au/sites/climatechange authority.gov.au/files/RET-Review-20120820.pdf (accessed Dec.12, 2013).

[3] Renewable Energy Target, Australian Government Department of Environment, 2001 [Online], http://www.climatechange.gov.au/reducing-carbon/renew able-energy (accessed Dec.12, 2013).

[4] Clean Energy in Victoria 2011-2012, Clean Energy Council, [Online], http://www.cleanenergycouncil.org.au/policy-advocacy/r eports.html (accessed Dec.10, 2013).

[5] Australian Government, Bureau of Meterology Australia, 2013, Australia's Official Weather Forecasts \& Wheather Radar-Bureau of Meteorology [Online], http://www.bom.gov.au (accessed Nov.15, 2013).

[6] D.R. Nielson, Solar radiation, The Nielsens Web site, 2005, http:/home.iprimus.com.au/nielsens/solrad.html, (accessed Dec.10, 2013).

[7] J.P. Dunlop, Photovoltaic Systems, 2011.

[8] State of Governement Victoria, Sustainability Victoria Solar [Online],

2012,
http://www.sustainability.vic.gov.au/Publications-and-Re search/Knowledge-archive/Solar (accessed Dec.12, 2013).

[9] Global Wind Energy Council Home Page, 2012, http://www.gwec.net/global-figures/graphs (accessed Nov.15, 2013).

[10] A.R. Jha, Wind Turbine Technology, Taylor \& Francis, USA, 2011.

[11] T. Ackermann, Wind Power in Power Systems, Vol. 140, Wiley Online Library, USA, 2005.

[12] J. Twidell, G. Paul, Wind Power, Chelsea Green Publishing Company, Vermont, USA, 2001,

[13] Victoria State Government, Sustainability of Victoria Wind Home Page, 2012, http://www.sustainability.vic.gov.au/Publications-and-Re search/Research/Renewable-energy-resources/Wind (accessed Dec.12, 2013).

[14] Homer energy, HOMER Web site 2013, http://homerenergy.com/software.html (accessed Nov.10, 2013).

[15] G. Dalton, D. Lockington, T. Baldock, Case study feasibility analysis of renewable energy supply options for small to medium-sized tourist accommodations, Renewable Energy 34 (2009) 1134-1144.

[16] J. Dekker, M. Nthontho, S. Chowdhury, S. Chowdhury, Economic analysis of PV/diesel hybrid power systems in different climatic zones of South Africa, International Journal of Electrical Power \& Energy Systems 40 (2012) 104-112.

[17] M. Beccali, S. Brunone, M. Cellura, V. Franzitta, Energy, economic and environmental analysis on RET-hydrogen systems in residential buildings, Renewable Energy 33 (2008) 366-382.

[18] A.N. Celik, Techno-economic analysis of autonomous PV-wind hybrid energy systems using different sizing methods, Energy Conversion and Management 44 (2003) 1951-1968.

[19] G. Liu, M. Rasul, M. Amannuallah, M. Khan, Economic and environmental modeling of a photovoltaic-wind-grid hybrid power system in hot arid Australia, International Journal of Thermal and Environmental Engineering 1 (2010) 15-22.

[20] Wind turbine star, AEOLOS Web site, 2013, [Availbale Online]: http://www.windturbinestar.com (accessed Nov.10, 2013).

[21] B. Storage, Lead acid battery, Fridge \& Solar Web site, 2013, http://www.fridge-and-solar.net/batteries.htm (accessed Nov.10, 2013).

[22] G. Shafiullah, M. Amanullah, A.S. Ali, D. Jarvis, P. Wolfs, Prospects of renewable energy-A feasibility study in the australian context, Renewable Energy 39 (2012) 183-197. 